\title{
CHEMICALLY INDUCED MUTAGENESIS IN THE KING OYSTER MUSHROOM Pleurotus eryngii TO GENERATE HIGH-TEMPERATURE TOLERANT STRAIN
}

\author{
Urarux Romruen*, Sirinapa Thangsiri, Tida Pongsutas, Eakaphun Bangyeekhun
}

Department of Microbiology, Faculty of Science, Silpakorn University, Nakhon Pathom 73000, Thailand

Received - August 31, 2021; Revision - November 05, 2021; Accepted - December 14, 2021

Available Online - December 30, 2021

DOI: http://dx.doi.org/10.18006/2021.9(6).831.836

\section{KEYWORDS \\ Pleurotus eryngii \\ Mutation \\ Ethyl methane sulfonate \\ Methyl methane sulfonate \\ Tolerance}

\begin{abstract}
In this study, a high-temperature-tolerant strain of the king oyster mushroom (Pleurotus eryngii) was generated by chemical mutagenesis. Cultivation of $P$. eryngii generally involves incubating the mycelia at $25^{\circ} \mathrm{C}$ and then moving the spawns for further incubation at $18^{\circ} \mathrm{C}$ for fruitification. However, in tropical countries, the temperature is a major concern in the production of oyster mushroom where the average temperature is $32^{\circ} \mathrm{C}$. In the current study, the mycelia were treated with ethyl methane sulphonate (EMS) or methyl methane sulphonate (MMS) for chemical-induced mutation. Seven mutants (EMS 1, 2, 6, 26, 35, 36, and 38) from EMS mutagenesis exhibited higher growth rates than the wildtype strain at $32^{\circ} \mathrm{C}$. However, mutant strains from MMS mutagenesis showed a low growth rate when compared with wild-type. On sawdust substrate, the spawn running conditions for these strains were performed at $32^{\circ} \mathrm{C}$, and fruitification occurred at $18^{\circ} \mathrm{C}$. The yield and biological efficiency of EMS 36 and 38 mutants were higher than those of the wild-type strain. The activities of cellulase and xylanase of EMS 36 and 38 mutants showed that both these mutants had higher activities than the wild-type strain which may influence mushroom production. Therefore, these EMS 36 and 38 mutants can be cultivated in tropical countries, which could provide a high yield and reduce the cost during spawn running step.
\end{abstract}

* Corresponding author

E-mail: urarux12@gmail.com (Urarux Romruen)

Peer review under responsibility of Journal of Experimental Biology and Agricultural Sciences.

Production and Hosting by Horizon Publisher India [HPI] (http://www.horizonpublisherindia.in/).

All rights reserved.
All the articles published by Journal of Experimental Biology and Agricultural Sciences are licensed under a Creative Commons Attribution-NonCommercial 4.0 International License Based on a work at www.jebas.org.

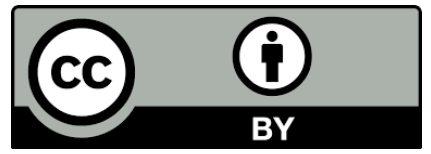




\section{Introduction}

The king oyster mushroom ( $P$. eryngii) belongs to the order Agaricales, the family Apiaceae (Zervakis et al., 2014). Recently, the industrial cultivation of $P$. eryngii has been increasing in Europe, Asia, and North America (Estrada \& Royse, 2007). For mushroom cultivation, the mycelial growth and primordia formation steps are performed at temperature ranges of $25^{\circ} \mathrm{C}-28^{\circ} \mathrm{C}$ and $10^{\circ} \mathrm{C}-17^{\circ} \mathrm{C}$, respectively (Ruhl \& Kues, 2007). Hence, the cultivation of $P$. eryngii in tropical countries, where the average temperature (about $32^{\circ} \mathrm{C}$ ) is higher than the temperature needed for cultivation. In these countries, optimum production of $P$. eryngii requires the use of a temperature controller, which resulted in higher costs or cost-inefficiency. Therefore, this study was conducted to generate a hightemperature-tolerant strain of $P$. eryngii to overcome this problem.

Recently, several studies have been conducted on mutagenesis in fungi to develop new strains with desired characteristics using various methods such as transformation and chemical and physical mutagenesis. To improve yield, mushrooms have been mutated by various methods. Bangyeekhun et al. (2020) exposed Volvariella volvacea by UV and reported that mutant strains showed a $30 \%$ higher yield than the parental strain. Romruen \& Bangyeekhun (2017) mutated the $P$. eryngii by using Agrobacterium mediated transformation. These researchers obtained four mutants but among these four, only one mutant has significantly higher fresh weight and biological efficiency (BE) as compared to the wield strains.

Further, chemical mutagenesis is considered to be convenient and easy because it involves very few steps. Previous studies have been suggested a tremendous success of chemical mutagenesis in mushrooms cultivation. Ethylmethanesulphonate (EMS) and methylmethanesulphonate (MMS) are categorized as alkylating agents and these induced mutations via DNA damage (Griffiths et al., 2005; Lundin et al., 2005). EMS and MMS have been successfully used for mutagenesis in various fungi. EMS has been successfully employed to induce the mutagenesis in various mushroom verities such as Volvariella volvacea, Flammulina velutipes, and P. ostreatus (Liu et al., 2011; Lin-Zhi et al., 2013; Sharma \& Sharma, 2014; Teimoori et al., 2014) while MMS has been successfully induced mutation in Hypsizygus marmoreus (Lee et al., 2011).

The current study was carried out to evaluate the mutagenesis properties of two chemical mutagens (EMS and MMS) in $P$. eryngii. Further, the yield, biological efficiency (BE), enzymatic activities (cellulase and xylanase), and the day to harvest were investigated in the mutant and wield types.

\section{Materials and Methods}

\subsection{Chemical mutagenesis}

P. eryngii cultured on potato dextrose agar (PDA) at $25^{\circ} \mathrm{C}$ for 10 days. Then, the agar was cut for 120 pieces with a diameter of 0.2 $\mathrm{cm}$ and treated with $50 \mathrm{~mL}$ of EMS and MMS as mutagens under appropriate conditions (based on the results of preliminary experiments of the same author). For EMS mutagenesis, the mycelia were treated with $0.25 \%$ (v/v) EMS and incubated at $32^{\circ} \mathrm{C}$ and $180 \mathrm{rpm}$ for $1 \mathrm{~h}$. For MMS mutagenesis, the mycelia of $P$. eryngii were treated with $0.2 \%(\mathrm{v} / \mathrm{v}) \mathrm{MMS}$ at $32^{\circ} \mathrm{C}$ and $180 \mathrm{rpm}$ for $45 \mathrm{~min}$. After mutagenesis, the mycelial plugs were filtered and washed with sterile distilled water three times.

\subsection{Selection and growth rate of mutants}

The mutants that survived were transferred to PDA and incubated at $32^{\circ} \mathrm{C}$ for 5 days to determine the relative growth rate by measuring the colony diameter. The relative growth rate was computed as follows: growth rate of mutant strain/growth rate of the wild-type strain. Mutants whose relative growth was higher than that of the wild-type strain were chosen for further study.

\subsection{Yield and biological efficiency (BE)}

The wild and mutant strains were inoculated into sawdust substrate, which was prepared by mixing $10 \mathrm{~kg}$ of para rubber wood sawdust, $0.5 \mathrm{~kg}$ of rice bran, $0.1 \mathrm{~kg}$ of lime (calcium oxide), $0.25 \mathrm{~kg}$ of calcium sulphate, $20 \mathrm{~g}$ of Epsom salt (magnesium sulphate), and 65-70 L of water. The substrate was packed into heat-resistant bags, containing $900 \mathrm{~g}$ per bag. These bags were sealed and autoclaved at $121^{\circ} \mathrm{C}$ for $20 \mathrm{~min}$.

The mycelial plug was inoculated and incubated at $32^{\circ} \mathrm{C}$ until grains became fully colonized. Then, the bags were inoculated with the spawn $(10 \mathrm{~g} / \mathrm{bag})$ and divided into four conditions as described in Table 2. The bags were incubated until the mycelium covered the substrate bag completely and were kept open for the formation of fruit bodies (80-90\% relative humidity). The weight of freshly harvested mushroom was measured (wet weight), and the BE was calculated using the total mushroom yield from each flush as follows:

$\mathrm{BE}(\%)=($ fresh fruiting body yield/dry weight of substrate $) \times 100$

\subsection{Cellulase and Xylanase activities}

The mutants were grown in a liquid medium (Lee et al., 2001) containing $2 \%$ sawdust and incubated at $32^{\circ} \mathrm{C}$ and $180 \mathrm{rpm}$ for 18 days. Cultures were harvested by filtering through cheesecloth. Cellulase and xylanase activities were measured by the 3,5dinitrosalicylic acid (DNSA) method (Miller, 1972). For this, $0.5 \mathrm{~mL}$ 
of the culture filtrate was mixed with $0.5 \mathrm{~mL}$ of $1 \%$ carboxymethyl cellulose (CMC) or $1 \%$ xylan in $0.05 \mathrm{M}$ sodium acetate buffer $(\mathrm{pH}$ 5.0). For blank, $1 \% \mathrm{CMC}$ or $1 \%$ xylan was added after incubation. The reaction mixtures were incubated at $45^{\circ} \mathrm{C}$ for $60 \mathrm{~min}$, and 1 $\mathrm{mL}$ of DNSA reagent was added to each tube. The reaction mixtures were incubated in a vigorously boiling water bath for 10

Table 1 The relative growth of mutants by using EMS and MMS

as mutagens

\begin{tabular}{|cccc|}
\hline \multicolumn{2}{|c|}{ EMS } & \multicolumn{2}{c|}{ MMS } \\
Strains & $\begin{array}{c}\text { Relative } \\
\text { growth }\end{array}$ & Strains & $\begin{array}{c}\text { Relative } \\
\text { growth }\end{array}$ \\
\hline Wild type (PE) & 1.00 & Wild type (PE) & 1.00 \\
\hline EMS 1 & 1.17 & MMS 1 & 0.85 \\
\hline EMS 2 & 1.42 & MMS 2 & 0.85 \\
\hline EMS 6 & 1.75 & MMS 3 & 0.65 \\
\hline EMS 26 & 1.23 & MMS 4 & 0.46 \\
\hline EMS 35 & 1.35 & MMS 5 & 0.46 \\
\hline EMS 36 & 1.35 & MMS 6 & 0.39 \\
\hline EMS 38 & 1.16 & MMS 7 & 0.39 \\
\hline
\end{tabular}

min and then transferred to a cold-water bath for 3 minutes. The developed color was measured using a spectrophotometer at 540 nm. The absorbance of the sample tubes was translated into glucose production during the reaction using a glucose standard curve. One unit (U) of enzyme activity was defined as the amount of enzyme that produced $1 \mu \mathrm{mol}$ of reducing sugar per minute under the conditions assayed.

\subsection{Statistical analysis}

The data from three independent experiments were analyzed using one-way ANOVA and Tukey's test using the program SPSS 11.0.

\section{Results}

\subsection{Selection of mutants}

EMS and MMS are alkylating agents which can cause DNA damage by the ethylation and methylation of DNA, respectively. These chemicals have been used as a mutagen in various studies (Shah et al., 2016; Volkova et al., 2020). After the induction of chemical mutagenesis, the relative growth rates of the mutants were determined by incubating these wild and mutant strains at

Table 2 Fresh weights, biological efficiency (BE) and day to harvest of wild type (PE) and mutant strains (EMS 1, 2, 6, 26, 35, 36 and 38) when were cultivated in selected condition

\begin{tabular}{|c|c|c|c|c|c|c|}
\hline Conditions & Temp. of spawn run $\left({ }^{\circ} \mathrm{C}\right)$ & Temp. of fruiting $\left({ }^{\circ} \mathrm{C}\right)$ & Strains & Fresh weight (g) & $\mathrm{BE}(\%)$ & Day to harvest (d) \\
\hline \multirow{8}{*}{1} & \multirow{8}{*}{25} & \multirow{8}{*}{18} & PE & $82.67 \pm 0.58^{\mathrm{abc}}$ & $19.00 \pm 0.13^{\mathrm{abc}}$ & $66.33 \pm 2.31^{\text {def }}$ \\
\hline & & & EMS 1 & $80.00 \pm 8.66^{\mathrm{bcd}}$ & $18.39 \pm 1.99^{\text {bcd }}$ & $68.33 \pm 3.06^{\text {cde }}$ \\
\hline & & & EMS 2 & $31.67 \pm 2.89^{f}$ & $7.28 \pm 0.66^{\mathrm{f}}$ & $73.33 \pm 2.89^{\mathrm{abc}}$ \\
\hline & & & EMS 6 & $31.67 \pm 2.89^{f}$ & $7.28 \pm 0.66^{\mathrm{f}}$ & $63.67 \pm 0.58^{\text {ef }}$ \\
\hline & & & EMS 26 & $70.00 \pm 8.66^{\text {cde }}$ & $16.09 \pm 1.99^{\text {cde }}$ & $62.00 \pm 0.00^{\mathrm{f}}$ \\
\hline & & & EMS 35 & $96.67 \pm 5.77^{\mathrm{a}}$ & $22.22 \pm 1.33^{\mathrm{a}}$ & $68.67 \pm 2.52^{\text {cde }}$ \\
\hline & & & EMS 36 & $63.33 \pm 2.89^{\mathrm{e}}$ & $14.56 \pm 0.66^{\mathrm{e}}$ & $62.67 \pm 1.15^{\mathrm{ef}}$ \\
\hline & & & EMS 38 & $65.00 \pm 5.00^{\mathrm{de}}$ & $14.94 \pm 1.15^{\mathrm{de}}$ & $66.33 \pm 2.31^{\mathrm{def}}$ \\
\hline \multirow{8}{*}{2} & \multirow{8}{*}{32} & \multirow{8}{*}{18} & $\mathrm{PE}$ & $65.00 \pm 3.00^{\mathrm{de}}$ & $14.94 \pm 0.69^{\mathrm{de}}$ & $72.00 \pm 1.00^{\text {bcd }}$ \\
\hline & & & EMS 1 & $26.67 \pm 2.89^{f}$ & $6.13 \pm 0.66^{\mathrm{f}}$ & $73.00 \pm 1.73^{\mathrm{abc}}$ \\
\hline & & & EMS 2 & $21.67 \pm 1.89^{f}$ & $4.98 \pm 0.66^{\mathrm{f}}$ & $74.00 \pm 3.46^{\mathrm{abc}}$ \\
\hline & & & EMS 6 & $71.67 \pm 7.64^{\text {bcde }}$ & $16.48 \pm 1.76^{\text {bcde }}$ & $74.33 \pm 1.15^{\mathrm{abc}}$ \\
\hline & & & EMS 26 & $71.67 \pm 7.64^{\text {bcde }}$ & $16.48 \pm 1.76^{\text {bcde }}$ & $79.00 \pm 2.00^{\mathrm{a}}$ \\
\hline & & & EMS 35 & $26.67 \pm 2.89^{\mathrm{f}}$ & $6.13 \pm 0.66^{\mathrm{f}}$ & $75.00 \pm 2.00^{\mathrm{ab}}$ \\
\hline & & & EMS 36 & $96.67 \pm 7.64^{\mathrm{a}}$ & $22.22 \pm 1.76^{\mathrm{a}}$ & $71.00 \pm 1.73^{\mathrm{bcd}}$ \\
\hline & & & EMS 38 & $86.67 \pm 2.89^{\mathrm{ab}}$ & $19.92 \pm 0.66^{\mathrm{ab}}$ & $72.33 \pm 0.58^{\mathrm{bcd}}$ \\
\hline 3 & 32 & 25 & All strains & - & - & - \\
\hline 4 & 32 & 32 & All strains & - & - & - \\
\hline
\end{tabular}

Journal of Experimental Biology and Agricultural Sciences http://www.jebas.org 


\subsection{Cellulase and xylanase activities}

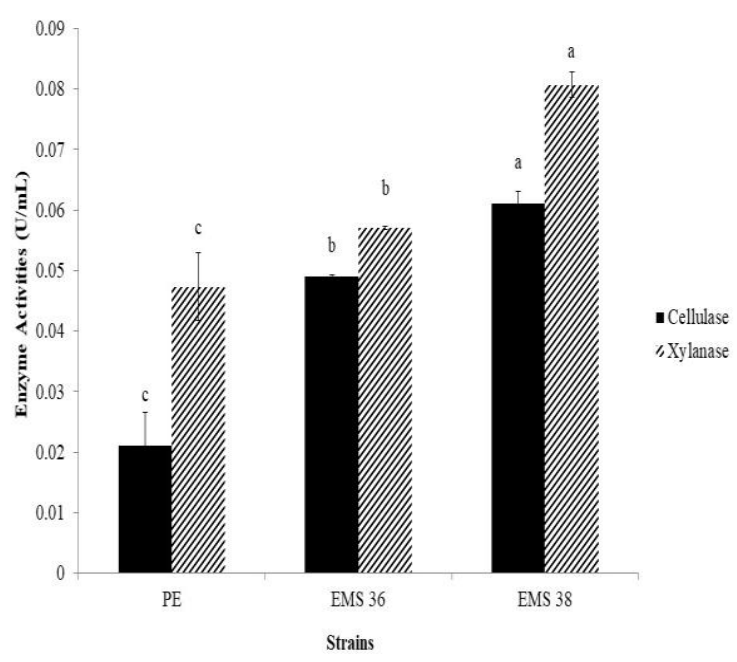

Figure 1 The cellulase and xylanase activities of wild type (PE) and are the means of triplicate experiments, error bars were SD the letter indicates the statistically significant difference $(\mathrm{p}<0.05)$.

$32^{\circ} \mathrm{C}$ for 5 days. From the selected 120 pieces of mycelial plugs, 48 and 53 pieces were survived after treatment with MMS and EMS, respectively. Furthermore, in MMS-induced mutagenesis, all mutants showed a relatively lower growth rate as compared to the wild strains (Table 1). However, the relative growth rates of seven EMS-induced mutant strains (EMS 1, 2, 6, 26, 35, 36, and 38) were higher than that of the wild-type strain (Table 1). Thus, these seven strains from EMS mutagenesis were selected for further characterization.

\subsection{Yield, BE and day to harvest}

The seven strains (EMS 1, 2, 6, 26, 35, 36, and 38) were cultured on sawdust substrate using the bag culture method. The inoculated bags were divided into four conditions as described in Table 2. The yield (fresh weight), BE, and the day to harvest were compared with those of the wild-type strain. The results showed that the spawn running step performed better at 25 and $32^{\circ} \mathrm{C}$, while the induction of fruiting bodies occur only at $18^{\circ} \mathrm{C}$ (conditions 1 and 2; Table 2). In other conditions, the mycelia could be grown, but there was no fruiting body production (conditions 3 and 4; Table 2). However, the morphology of mutant and wild-type strains was not different.

In general, $P$. eryngii can be cultivated at $25^{\circ} \mathrm{C}$ for spawn running and $18^{\circ} \mathrm{C}$ for fruiting body production. In condition 2 , the fresh weight and BE of two mutants (EMS 36 and 38) were significantly higher than those of the wild-type strain. Regarding the day to harvest, EMS 36 and 38 mutants were similar to the wild-type strain (condition 2; Table 2).
EMS-induced mutagenesis not only influenced the growth rates and mushroom production but might also affect the enzymatic activities of the treated mushroom. To confirm this hypothesis, the activities of cellulase and xylanase were investigated in this study. Mycelia were grown in the liquid medium containing $2 \%$ sawdust as substrate. The cultures were incubated at $32^{\circ} \mathrm{C}$ for 18 days. Then, the enzyme activities were measured from the culture filtrate. The results demonstrated that the activities of both these enzymes from EMS 36 and 38 mutants were enhanced when the mycelia were grown at $32^{\circ} \mathrm{C}$ (Figure 1). Regarding cellulase activity, EMS 38 produced the highest activity $(0.061$ $\mathrm{U} / \mathrm{mL})$, followed by EMS $36(0.049 \mathrm{U} / \mathrm{mL})$ and wild-type $(0.020$ $\mathrm{U} / \mathrm{mL}$ ) strains. Similarly, in the case of xylanase, EMS 38 showed the highest at $0.081 \mathrm{U} / \mathrm{mL}$, whereas those of EMS 36 and wild-type strain were 0.057 and $0.047 \mathrm{U} / \mathrm{mL}$, respectively.

\section{Discussion}

Chemical mutagenesis has been successfully used for induced mutation in mushroom to obtain the desired characteristics. Lee et al. (2011) treated the basidiospores of H. marmoreus with MMS and obtained two mutant strains that exhibited increased fruiting body production. Further, V. volvacea and $P$. ostreatus have been mutated using EMS to obtain a cold-tolerant and a low-sporing strain, respectively (Liu et al., 2011; Sharma \& Sharma, 2014; Teimoori et al., 2014). Interestingly, the high-temperature-tolerant strain of $F$. velutipes was successfully generated using EMS, and the mutant strains could be grown with fruiting body formation at high temperatures. Moreover, the BE of the mutants was increased under this condition (Lin-Zhi et al., 2013). Since P. eryngii has been generally cultivated at $18-25^{\circ} \mathrm{C}$, these conditions increased the cost of cultivation in tropical countries due to high energy consumption. Therefore, this study was carried out to reduce the cost, for this, the mutation was performed at $32^{\circ} \mathrm{C}$ which is the average temperature of the tropical countries.

In this study, the mycelia of seven mutant strains from EMS mutagenesis could be grown at $25^{\circ} \mathrm{C}$ and $32^{\circ} \mathrm{C}$. However, the fresh weight and $\mathrm{BE}$ of EMS 36 and 38 mutants were higher than those of the wild-type strain when cultivated at $32^{\circ} \mathrm{C}$ and fruitification at $18^{\circ} \mathrm{C}$. However, the day to harvest was longer for EMS 36 and 38 mutants under this condition than that for wild-type under condition 1, but the spawn was incubated at $32^{\circ} \mathrm{C}$ for spawn running, the ambient temperature in tropical countries. The use of a temperature controller was eliminated in this step, thus reducing the cost.

Induction of mutagenesis in P. eryngii using the Agrobacteriummediated transformation and UV irradiation method has been previously reported (Obatake et al., 2003; Kim et al., 2010; 
Romruen \& Bangyeekhun, 2017). In the present study, the yields of EMS 36 and 38 mutants were successfully enhanced. However, the yields of EMS 1, 2, and 35 were lower than wild-type strain in condition 2.

Subsequently, the activities of cellulase and xylanase of both these mutants were investigated. For this, $P$. eryngii was cultivated on a lignocellulosic substrate that contains cellulose (50\%), hemicellulose (30\%), and lignin (20\%), it is required to produce lignocellulosic enzymes such as cellulase and xylanase (Sajith et al., 2016). It has been reported that the production of mushroom such as Pleurotus spp. and $V$. volvacea is related to the activities of these enzymes, and high enzyme activity was found in high-yield strains (Kurt \& Buyukalaca, 2010; Zhao et al., 2010). In this study, the activities of cellulase and xylanase of EMS 36 and 38 mutants were higher than those of the wild-type strain, which may be the reason for the high yield of these mutant strains.

Lui et al. (2020) generated new mushroom strains by crossbreeding between monokaryon of $P$. tuoliensis or $P$. eryngii. Two new strains were obtained and show higher biological efficiency than parents. However, the dikaryotic strain of P. eryngii was used in this study. The current study resulted in the production of hightemperature tolerant strain. Therefore, both monokaryotic and dikaryotic strains could be used to create new strains.

\section{Conclusions}

High-temperature tolerant strain of $P$. eryngii was obtained by treatment with EMS but not from MMS. The fresh weight and BE of two mutant strains (EMS 36 and 38) were higher than wild type when spawn running at ambient temperature $\left(32^{\circ} \mathrm{C}\right)$ and fruiting at $18^{\circ} \mathrm{C}$. In addition, the enzyme activity of $P$. eryngii was successfully enhanced by chemical mutagenesis for the first time. This study showed cellulase and xylanase activities of 2 strains were improved. From the results of the present study, the energy consumption and cost in the spawn running step was reduced. There was an advantage for $P$. eryngii industrial cultivation in a tropical country.

\section{Acknowledgement}

This work was supported by a grant from the Faculty of Science, Silpakorn University (SFR-PRG-2561-01).

\section{Conflict of Interest: $\mathrm{Ni}$}

\section{References}

Bangyeekhun E, Sawetsuwannakul K, Romruen U (2020) UVinduced mutagenesis in Volvariella volvacea to improve mushroom yield. Songklanakarin Journal of Science and Technology 42: 910-916.
Estrada AER, Royse DJ (2007) Yield, size and bacterial blotch resistance of Pleurotus eryngii grown on cottonseed hulls/oak sawdust supplemented with manganese, copper and whole ground soybean. Bioresource Technology 98: 1898-1906.

Griffiths AJF, Wessler SR, Lewontin RC, Gelbart WM, Suzuki DT, Miller JH (2005) An Introduction to Genetic Analysis. W. H. Freeman and Company, New York.

Kim S, Sapkota K, Choi BS, Kim SJ (2010) Expression of human growth hormone gene in Pleurotus eryngii. Central European Journal of Biology 5: 791-799.

Kurt S, Buyukalaca S (2010) Yield performances and changes in enzyme activities of Pleurotus spp. ( $P$. ostreatus and P. Sajorcaju) cultivated on different agricultural wastes. Bioresource Technology 101: 3164-3169.

Lee CC, Wong DWS, Robertson GH (2001) Cloning and characterization of two cellulase genes from Lentinula edodes. FEMS Microbiology Letters 205: 355-360.

Lee J, Kang HW, Kim SW, Lee CY, Ro HS (2011) Breeding of new strains of mushroom by basidiospore chemical mutagenesis. Mycobiology 39: 272-277.

Lin-Zhi K, Fei H, Jun-Fang L, Li-Qiong G, Wei-Fang B (2013) Breeding of new high-temperature-tolerant strains of Flammulina velutipes. Scientia Horticulturae 151: 97-102.

Liu X, Liu S, Yea L, Wu X (2020)Breeding and fruiting evaluation of new strains by the interspecific mating of the high commercial potential mushroom Pleurotus tuoliensis with its closely related $P$. eryngii. Scientia Horticulturae 271: 1-8.

Liu Z, Zhang K, Lin J, Guoa L (2011) Breeding cold tolerance strain by chemical mutagenesis in Volvariella volvacea. Scientia Horticulturae130: 18-24.

Lundin C, North M, Erixon K, Walters K, Jenssen D, Goldman AS, Helleday T (2005) Methyl methanesulfonate (MMS) produces heat-labile DNA damage but no detectable in vivo DNA doublestrand breaks. Nucleic Acids Research 33: 3799-3811.

Miller LG (1972) Use of dinitrosalicylic acid reagent for determination of reducing sugar. Analytical Chemistry 31: 426-429.

Obatake Y, Murakami S, Matsumoto T, Fukumasa-Nakai Y (2003) Isolation and characterization of a sporeless mutant in Pleurotus eryngii. Mycoscience 44: 33-40.

Romruen U, Bangyeekhun E (2017)Yield improvement of the king oyster mushroom, Pleurotus eryngii, by transformation of its cellulase gene. Biologia 72: 140-144. 
Ruhl M, Kues U (2007) Mushroom Production. In: Kües U (Ed.),Wood production, wood technology, and biotechnological impacts, Universitätsverlag Göttingen, Germany.

Sajith S, Priji P, Sreedevi S, Benjamin S (2016) An overview on fungal cellulases with an Industrial Perspective. Journal of Nutrition \& Food Sciences 6: 1-13.

Shah D, Kamili AN, Wani AA, Nazir N, Sajad N, Khan I, Parray JA, Shah S (2016) Mutagenic Action of Ethyl Methanesulphonate (EMS): A Review. Journal of Research and Development 16: 6368.

Sharma R, Sharma BM (2014) Strain improvement in Pleurotus ostratus using UV light and ethyl methyl sulfonate as mutagens. African Journal of Microbiology Research 8: 432-436.

Teimoori BB, Pourianfar HR, Moeini MJ, Janpoor J (2014) Chemically and physically induced mutagenesis in basidiospores of oyster mushroom Pleurotus ostreatus var. florida. International Journal of Advanced Research 2: 915-921.

Volkova NV, Meier B, González-Huici V, Bertolini S, Gonzalez S, Vöhringer H, Abascal F, Martincorena I, Campbell PJ, Gartner A, Gerstung M (2020) Mutational signatures are jointly shaped by DNA damage and repair. Nature Communications 11:1-15.

Zervakis GI, Ntougias S, Gargano ML, Besi MI, Polemis E, Typas MA, Venturella G (2014) A reappraisal of the Pleurotus eryngii complex-new species and taxonomic combinations based on the application of a polyphasic approach, and an identification key to Pleurotus taxa associated with Apiaceae plants. Fungal Biology118: 814-834.

Zhao FY, Lin JF, Zeng XL, Guo LQ, Wang YH, You LR (2010)Improvement in fruiting body yield by introduction of the Ampullariacrossean multi-functional cellulase gene into Volvariella volvacea. Bioresource Technology 101: 6482-6486. 